\title{
ANALYSIS OF FRICTION AND WEAR COEFFICIENT IN BEARING STEEL WITH IRON OXIDE NANOPARTICLE LUBRICANT
}

\author{
Lilian Andrade dos Santos ${ }^{1}$, Victor Martins dos Santos ${ }^{1}$, Ana Emília Guedes ${ }^{2}$
}

${ }^{1,2}$ Mechanical Engineerring in Northern University Center (UNINORTE) - Manaus-AM.

Email: 1iliandrade.1010@gmail.com, victorsantos.mec@gmail.com, ana.guedes@ uninorte.com.br

Received: April 10 ${ }^{\text {th }}, 2019$

Accepted: May 17th 2019

Published: June $30^{\text {th }}, 2019$

Copyright (C2016 by authors and Institute of Technology Galileo of Amazon (ITEGAM). This work is licensed under the Creative Commons Attribution International License (CC BY 4.0). https://creativecommons.org/lice nses/by/4.0/

\begin{abstract}
Nanotechnology is a subject in many studies conducted in the technological areas and it has been showing a great importance on the development of advanced research in various areas. In the gradual evolution of lubricants as well as in performance improvement oxide nanoparticles have been used as chemical additives for the development of lubricating oils. Therefore, the aim of this article is to study the advantages and disadvantages on the use of iron oxide nanoparticles in synthetic oil based on friction and wear tests. The nanoparticles was obtained the hydrothermal aided by microwaves and after characterized through tests, XRD and SAXs. Tribological experiments were performed with aditived oil, featuring very different results than expected.
\end{abstract}

Keywords: Nanoparticles, oxides, additives, lubricant.

\section{INTRODUTION}

Tribological studies on lubrication area had advanced substantially, for being very useful in various industrial segments [1]. Moreover, it is necessary to combat unwanted friction, once that the excessive contact between two materials surfaces will eventually cause wear to the machine or even a reduction in the quality of the final product [2]. With the aid of nanotechnology, it is possible to observe different ways to improve the performance of lubricating oils [3]. However, with a wide range of possible additives that may be used or added to lubricant, an in-depth study is necessary. In the face of barriers to obtain nanoparticles to analyze their coefficients due to their size, it is necessary to keep abreast of new synthesis technologies, however, with their success, the possibility of using additives in their positioning, has as obtained more satisfactorily and efficiently than compared to commonly used oils.

This generates profits for the company, making the effective product, in addition to increasing the client reliability.

Usually different types of lubricants have some additive in their composition, these substances make it possible the formation of anti-wear tribofilms between the structures or in any other application [4]. The use of an oxide based nanoparticles increase the range of application to higher temperatures and pressure, as

well as excellent results in friction reduction, being used as antiwear additive [5]. The purpose of this article study the advantages and disadvantages on the use of iron oxide nanoparticles in synthetic oil based on friction and wear tests. The characterization tests, XRD and SAXs, were performed along with tribological experiments, ball on plan, to study the wear and friction.

\section{MATERIALS AND METHODS \\ II.1 NANOPARTICLES PRODUCTION}

In order to use iron oxide nanoparticles, it is necessary to produced it. Thus, the method chosen for the synthesis of iron oxide nanoparticles was the hydrothermal aided by microwaves, assuming the parameters adopted by [6], as described in Table 1. These are superparamagnetic nanoparticles, so they were called SPION33 in this study. 
Table 1: Synthesis steps of the iron oxide magnetic nanoparticles.

\begin{tabular}{|c|c|}
\hline Stage & $\begin{array}{c}\text { Obtaining the } \\
\text { Nanonparticles of Iron } \\
\text { Oxide. }\end{array}$ \\
\hline $\begin{array}{l}\text { Weighing and } \\
\text { hogenization }\end{array}$ & $\begin{array}{l}3.38 \mathrm{~g} \text { of } \mathrm{FeCl} 3- \\
6 \mathrm{H} 2 \mathrm{O} \text {, dispersed in } 15 \\
\mathrm{ml} \text { of } \mathrm{NH} 4 \mathrm{OH} \text {. The } \\
\text { heavy reagents are } \\
\text { placed under magnetic } \\
\text { stiming until } \\
\text { homogenization is } \\
\text { complete, about } 30 \\
\text { minutes, maintainig the } \\
\text { pH }=10 .\end{array}$ \\
\hline $\begin{array}{c}\text { Microwave } \\
\text { Reaction }\end{array}$ & $\begin{array}{l}\text { The mixture was } \\
\text { poured into a teflon } \\
\text { reactor and introduced } \\
\text { into microwave oven at } \\
300 \mathrm{~W} \text { power for } 2 \\
\text { minutes reaching } 95^{\circ} \mathrm{C} \\
\text { temperature. After that } \\
\text { they were centrifuged } \\
\text { and dried. }\end{array}$ \\
\hline
\end{tabular}

Source: [7].

The nanofluid microstructure can be manipulated and varied by adjusting the parameters, such as temperature, acidity, types and concentration of additives and reagents, including the order in which the additives are be added in the solution [8].

In this way, the synthesis of iron oxide nanoparticles by microwave is beneficial for these studies, because the user is able to manipulate the substance in several aspects in a simple way, with low cost and satisfactory speed. In addition to these competencies, since it occurs in a controlled environment, it ends up having no contact between the energy source and the container reaction.

\section{II.2 X-RAY DIFFRACTION CHARACTERIZATION (XRD)}

The X-ray diffraction characterization assay has a great importance in this study since it makes it possible to obtain the size of the 5rystallites in order to constitute the comparative study of energy and minimum time of iron oxide nanoparticle formation [9].

Therefore, in order to determine the crystallinity degree, the phase of the iron oxide that compose the sample and the size, the $\mathrm{X}$-ray diffraction (XRD) analysis is performed. The studies were carried out on a Shimatzu diffractometer, model 6000, equipped with the target of Cuka (1.5408 $\AA$ ), voltage of $4.0 \mathrm{kV}$ and current of $30 \mathrm{~mA}$. The scan made in the sample was processed from 10 to 80 degrees, with a step of 0.02 degrees and time of 3 seconds per step. The sample of the standard test is characterized by the technique in the equipment used.

The definition of the crystallites average size was determined by the shape, width and half height of a diffraction profile, and for this, the Scherrer equation was used [10].

\section{II.3 SMALL ANGLE X-RAY SCATERRING (SAXS) ON SPION33}

In this analysis, the camera SAXS (Anton Paar, Austria) coupled to an X-ray generator tube (PW3830-PANalytical, Holland), with the radiation of $\mathrm{Cu} \mathrm{Ka}$ wavelength of $0.1542 \mathrm{~nm}$, operating at $40 \mathrm{kV}$ and $50 \mathrm{~mA}$, was used to define the sample size SPION33 and analyze its structure.

After being vacuum and closed in a quartz capillary, containing an external diameter of $1 \mathrm{~nm}$ and a thickness of $10 \mathrm{~nm}$, the temperature control was performed in the sample by a thermostatized sample unit (TCS 120, Anton Paar). The scattering intensity measurements were displayed on an image plate (IP), with Cyclone detection system (Perkin Elmer, USA), and transformed through the Saxsquant (Anton Paar) software for onedimensional intensity.

The variation in the distribution of the electron density can be measured by the elastic scattering of the X-rays, which can register small angular variations $\left(0.1-10^{\circ}\right)$. For systems that do not have long-range crystalline order, the low-angle scattering has great utility, differentiating itself from other methods that use Xrays [11].

To perform the evaluation of the structure of the dispersed SPION33 in PAO synthetic oil (polyalfaolefin) a Small Angle Xray Scaterring - SAXS was performed (wavelength of $0.1 \mathrm{~nm}$ to $0.2 \mathrm{~nm}$ ), the oil is enriched with the Spion 33 sample and then it is dispersed in Toluene in order to perform the analysis. This analysis can determine various parameters of particle structures, from the average particle size, its shapes, to the pore size, distribution and the ratio between the volume and surfaces [12].

\section{II.4 TRIBOLOGICAL ASSAYS (HFRR)}

For the analysis of synthetic oil additivated with SPION33, it is necessary to perform a wear and lubricity test using tribological equipment with the HFRR method (High Frequency Reciprocating Rig). These tests were performed in the laboratory of Tribology and Structural Integrity Studies Group (GET) located at the Federal University of Rio Grande do Norte (UFRN).

This evaluation consists of a system that is submerged in a nanofluid, composed by a ball and a disc. The tribological pair (ball-disc) is placed on the respective HFRR brackets. The glass ball is attached to the bracket using a screw, so it is possible to perform only desired vector movements, similarly, the disc is attached to the HFRR sample bracket by two identical screws placed diametrically opposed. After this, the thermocouple is inserted into the predetermined hole in the disc sample bracket; then the maximum load is applied.

The ball performs alternating vector movements for 90 minutes on the disc surface, in a course of $1.00 \pm 0.02 \mathrm{~mm}$ under a frequency of $20 \pm 1 \mathrm{~Hz}$. The volume of nanofluid used is $(2.0 \pm$ $0.2 \mathrm{~mL}$ ). From this principle, a load with intensity of $10 \mathrm{~N}$ is applied on the ball against the disc, at a constant temperature of $50{ }^{\circ} \mathrm{C}$ of the lubricant, whose is verified to $1.7 \mathrm{~mm}$ of the contact between disc and ball.

It is possible to measure the coefficient of friction and, subsequently, the wear analysis during the performance of the assay. After completion, the specimens are cleaned and the size of the worn face on the steel disc is evaluated with the aid of a SEM (scanning electron microscopy), as well as the wear analysis in the glass ball.

The ball used in the HRFF assay is composed by borosilicate glass, which hardness is around 570 to $750 \mathrm{HV}$ and has a diameter of $6.0 \mathrm{~mm}$. The disc is made of AISI 52100 steel 
without treatment (190 - $210 \mathrm{HV})$, according to ASTM (1998). Its composed by: chromium (1.30 to $1.60 \%)$, carbon ( 0.98 to $1.10 \%)$, manganese $(0.25$ and $0.35 \%)$, silicon $(0.15$ to $0.35 \%)$ and maximum of $0.025 \%$ sulfur.

\section{II.5 SEM - SCANNING ELECTRON MICROSCOPY}

The SEM (Scanning Electron Microscopy) is equivalent to the use of a small diameter electron beam to study the surface of the sample, from point to point by continuous lines, transmitting the detector signal to a cathodic screen (technique used to monitor the corrosion of a metal surface), which the scan is distinctly synchronized with the incident beam. The beam is driven in a way to sweep the sample surface according to a rectangular mesh, in a system of deflection coils. The interaction of the incident beam with the sample surface results in the image signal. The detector is used to articulate the brightness of the monitor so the received signal can be observed. Most of the instruments used in this assay have a heated tungsten filament (W) heated as electron source, consuming a range of acceleration voltages from 1 to $50 \mathrm{Kv}$. Therefore, the beam is accelerated by the high tension applied between the filament and the anode (electrode where negative ions are moved when an electric current passes through an electrolytic cell). Then, it is focused on the sample by three electromagnetic lenses with a stop less than $4 \mathrm{~nm}$. After this, the beam that is applied in the sample produces electrons and photons that are collected by suitable detectors and transformed into a video signal [13].

The moment when the primary beam reaches the sample, part of the electrons diffuse and create a contact volume whose shape depends mainly on the acceleration tension and the atomic number of the sample.

In order to be discovered the particle and the electromagnetic rays that were established from the interaction of electron beam in the sample, one must return the surface of the sample so the detector can be reached. As the energy that the particle or rays reaches the detector, the maximum detection depth is obtained.

The supply of the image from the signal produced by the electronic scan of a surface has different characteristics. The interaction between the electronic beam and the sample material produce an image resulting from the amplification of this signal, from a MEV.

\section{RESUTS AND DISCUSSION}

\section{III.1 XRD}

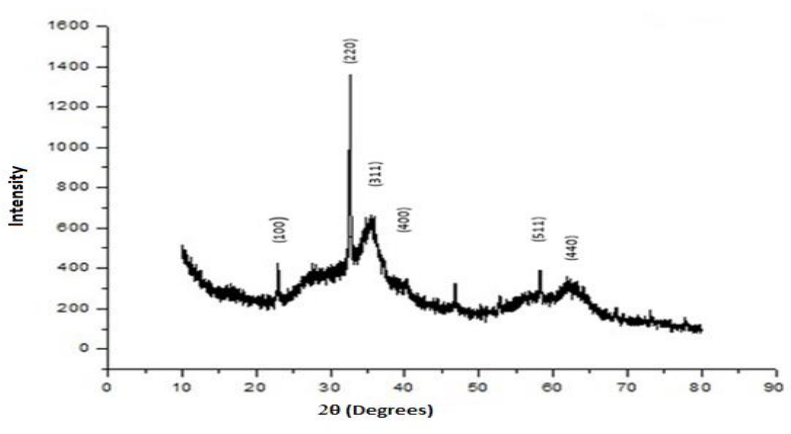

Figure 1: Diffractogram of SPION33.

Source: Authors, (2019).
To confront the crystallite size by XRD and SAXs, it is necessary to calculate the width and half height of the peak disposed at approximately $\mathrm{X} 0$, in the case of nanometric sizes of the order. The noisy diffractogram is a characteristic of a nanostructured material [14].

\section{III.2 SAX}

Through the analyses made in the SAXS curves profiles, it is possible to observe through the average size of the SPION33 the desired particle, since each one has its own characteristics [15].

The SAXS assay presents results on the nanoparticles agglomeration, geometric form, and also grants the data of the size of nanoparticles covered with oleic acid, wrapped by the oil droplet. Through the light scattering, the hydrodynamic volume of the nanoparticles is altered in radius of turning. When checking the samples average size, the turning radius represents the distance between the center of gravity and the surface of the ball [16].

Using the size equations performed by SAXS, it is possible to present simulated measures. To obtain the images, the data analysis software ATSAS 2.7.2 (https://www.emblhamburg.de/biosaxs/software.html) was used, where the information collected during the test was added (Figure 2).
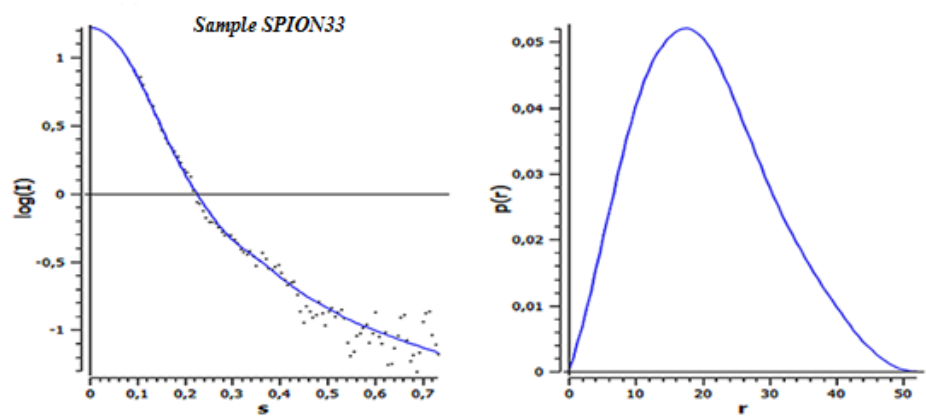

Figure 2: Maximum, minimum and average size calculation. Source: Authors, (2019).

Through this assay, it is possible to observe in Figure 2, the average, minimum and maximum size of SPION33. Nanoparticles with a maximum diameter of $51.98 \mathrm{~nm}$ were verified, and the average was around $15.87 \mathrm{~nm}$, with SPIONS33 of size smaller than the average.

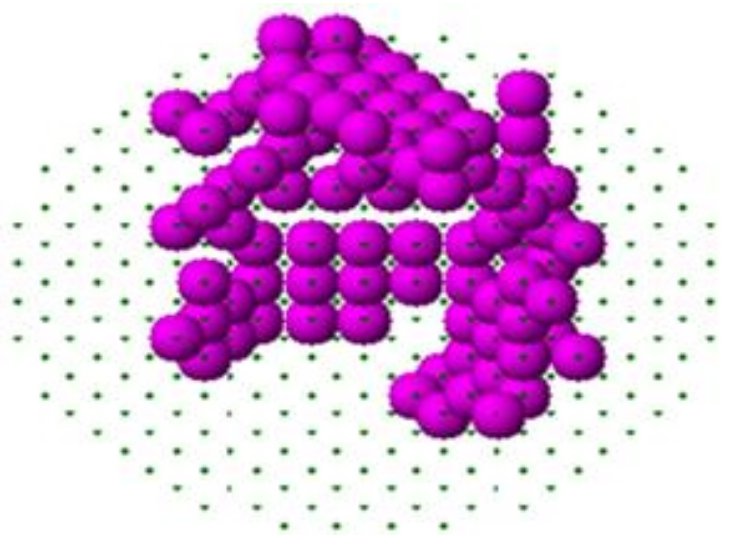

Figure 3: Nanoparticles agglomeration.

Source: Authors, (2019).

As shown in Figure 3, it is perceived the nanoparticles agglomeration, this is associated to the fact that there size is nanometric, thus it may cause the increase of surface energy in these materials. One way to reduce the nanoparticles agglomeration is to use a dispersing agent or to treat the surface with an encapsulation. These methods prevent or minimize the 
agglomeration of the nanoparticle due to an electrostatic repulsion and stearic impediment mechanisms [17].

The agglomeration type study is of great importance, because it has a significant influence on the tribological assays results, and It is essential for this study that the nanoaddial be incorporated into the oil in a way that no agglomerations or third body formation can be caused in the composition so that this does not occur, the correct choice of substance size and structure is of utmost importance [18].

Table 2 - Comparison of SPIONS sizes: XRD e SAXS.

\begin{tabular}{|c|c|c|c|}
\hline $\begin{array}{c}\text { Power/ } \\
\text { Time/ } \\
\text { Temperat } \\
\text { ure }\end{array}$ & $\begin{array}{c}\text { Descriptio } \\
\text { n of } \\
\text { Samples }\end{array}$ & $\begin{array}{c}\text { SPION33 } \\
\text { Medium Size } \\
\text { DRX- } \\
\text { WITHOUT } \\
\text { RECOVERY }\end{array}$ & $\begin{array}{c}\text { SPION33 } \\
\text { Medium Size } \\
\text { SAXS - } \\
\text { WITH } \\
\text { RECOVERY }\end{array}$ \\
\hline $\begin{array}{l}300 \mathrm{~W} \\
\mathbf{2} \mathbf{~ m i n} \\
\mathbf{9 5}^{\circ} \mathrm{C}\end{array}$ & $\begin{array}{c}\text { SPION33 } \\
\text { Maghemit } \\
\text { e/ } \\
\text { Hematite }\end{array}$ & $15 \mathrm{~nm}$ & $15,87 \mathrm{~nm}$ \\
\hline
\end{tabular}

Source: Authors, (2019).

Table 2 presents the comparison between the SPION33 sizes calculated by the XRD and SAXS analyses. The different results in each of the experiments is due to the sample being without coating and dry in the XRD analysis, while in the SAXS experiment, the SPION33 was covered and immersed in a droplet, so a larger average size is measured, when compared to the other [19] [20]. Both measurement techniques are accurate, however, factors must be considered, such as: comprehension of the difference between the equipment used for each analysis, which are based on different physical principles of size measurement, may result in different results. However, when the same equipment is used, with the same physical principles, the algorithms used and components in the machine vary according to the manufacturer, causing a discrepancy in the average size. Therefore, when analyzing the sizes verified in these items, even considering the thickness of the encapsulation measured in the SAXS assay, it is evident that the values are coherent and in accordance with the techniques and methodology applied [21].

\section{III.3 HFRR - LUBRICITY TEST}

The lubricity test measures the coefficient of friction of the two lubricants studied, the polyalphaolefin without the addition of the nanoparticle and with the addition of the nanoparticles in the synthetic lubricant. Both lubricants, throughout the test time, remained almost constant, with only a few variations relevant to the natural process, including contacts at high pressures (Figure 4).

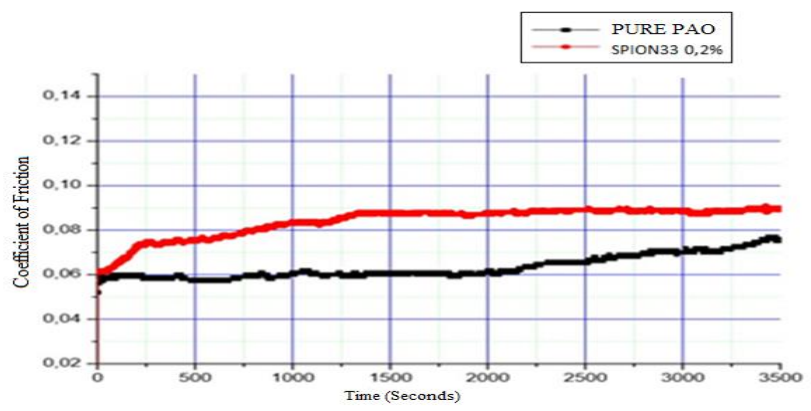

Figure 4: Lubricity test measures.

Source: Authors, (2019).
In addition, due to the wear phenomena that occurred throughout the process, it is a fact that, although the synthetic lubricant without additives showed a lower coefficient of friction during the whole test at the end of 3000 seconds, this difference was decreasing. The tendency was that, from 1250 seconds, there was greater constancy during the test.

At the beginning, the variation of the coefficient of friction with the additive oil is probably due to the aggregation of the nanoparticles as shown in the SAXS, where this agglomeration may have decreased exactly to 1250 seconds due to the very high contact of the process. With this, it may have dispersed these nanoparticles and tended to have an inclination to constancy and to decrease the same.

However, during the time of 3500 seconds, there was no improvement in aditicar with these nanoparticles, with this determined size and in synthetic oil. The main harmful cause was the agglomeration of these nanoparticles, which means that the dispersant used in the oil was not effective, had no contribution to the test. It means that for this size is not satisfactory, one can try for subsequent analyzes of these same tests using another dispersant and different sizes of nanoparticles.

It is observed that the wear trail in the center of the Eschar is more evident. This complements the lubricity tribological assay of the SAXS because the nanoparticles are agglomerated, thus increasing the mechanism of friction and consequently the wear. There was enough abrasive wear and adhesive wear for the same reason, it is necessary to see the size of the track on the edges, this evidence is not as clear as in the center (Figure 5).

III.4 SEM - Wear analysis

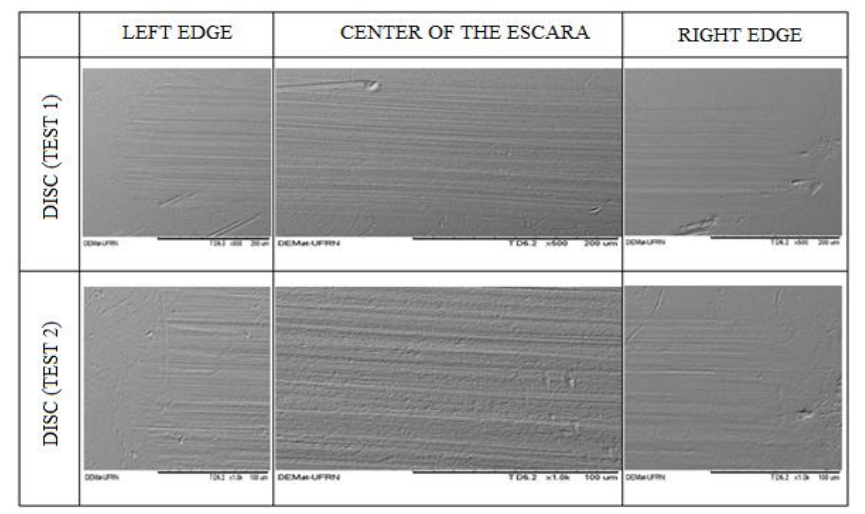

Figure 5: Wear analysis.

Source: Authors, (2019).

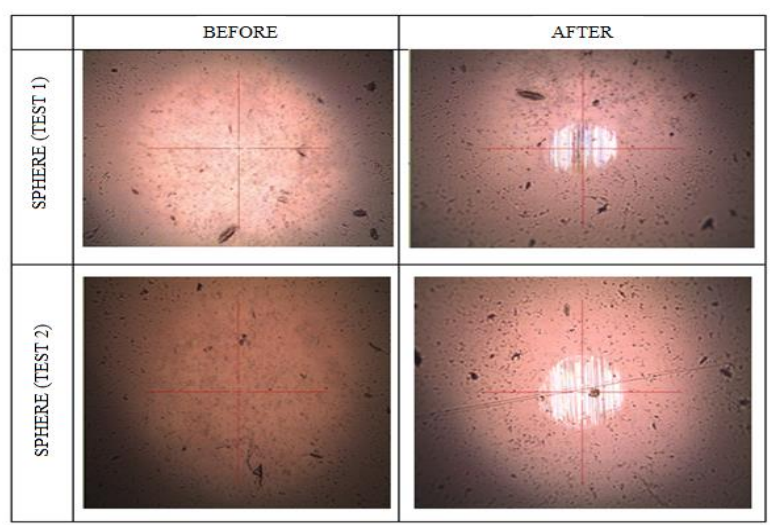

Figure 6: Images of the balls surface. Source: Authors, (2019). 
These images of the balls surface is one more proof that there was certainly agglomeration of the nanoparticles because the area worn in the ball is much larger and much more evident when the lubricating oil is enriched with the nanoparticles (Figure 6).

\section{CONCLUSIONS}

The nanoparticles were successfully obtained through the hydrothermal aided by microwaves method, showing a fast and efficient method. Based on the characterization of the nanoparticles by XRD and SAXS analyses, they proved to be efficient and accurate to the size characterization. The SAX proved to be efficient in terms of the size and the agglomeration phenomenon, indicating that the dispersant used was not efficient or effective to disaggregate the nanoparticles. It was not efficient in relation to the synthetic oil without the additive, emphasizing once again the exchange of the dispersant and the increase of number of lubricity test cycles to further investigate the potential use of nanoparticles in synthetic oil as lubricant under high contact pressure. The tribological assay proved that the SAX was right, showed the agglomeration. From the tests carried out, it is possible to prove the non-advantage of the use of iron oxide nanoparticles with this size and characterization (SPION33) as additive in polyalphaolefin synthetic oil as a mechanism of friction reducer.

\section{REFERENCES}

[1] Salvaro, D. B. (2015). Avaliação Tribológica de DLC em Regime de Lubrificação Mista. Florianópolis.

[2] Folle, L. F. (2008). Metodologia de Medição do Coeficiente de Atrito em Estampagem. Avaliação da Influência da Lubrificação e Condições Superficiais Via Simulação Numérica. Porto Alegre.

[3] Pereira, F., Trajano, M. F., Alves, S. M., Faccio, M., \& SILVA, P. S. (Março de 2012). Nanopartículas de Óxidos Como Aditivo Químico em Lubrificantes. $2^{\circ}$ Congresso Químico do Brasil.

[4] Salvaro, D. B. (2015). Avaliação Tribológica de DLC em Regime de Lubrificação Mista. Florianópolis.

[5] Chem, S., \& Liu, W. (2001). Caracterization and antiwear ability of nom coated $\mathrm{ZnS}$ nanoparticles and DDP-coated $\mathrm{ZnS}$ nanoparticles. Materials Research Bulletin.

[6] Guedes, A. E. (2017). Síntese e Caracterização de Nanopartículas Superparamagnéticas para Aditivação de Lubrificantes Industriais.

[7] Guedes, A. E. (2017). Síntese e Caracterização de Nanopartículas Superparamagnéticas para Aditivação de Lubrificantes Industriais.

[8] Guedes, A. E. (2017). Síntese e Caracterização de Nanopartículas Superparamagnéticas para Aditivação de Lubrificantes Industriais.

[9] Guedes, A. E. (2017). Síntese e Caracterização de Nanopartículas Superparamagnéticas para Aditivação de Lubrificantes Industriais.

[10] A. C. F. M. Costa, M. A. (2006). Síntese e caracterização de nanopartículas de $\mathrm{TiO} 2$.
[11] Blazek, K., \& Gilbert, E. (2011). Application of Small-Angle $X$-ray and Neutron Scattering Techniques to the Characterisation of Starch Structure: A Review. Carbohydrates Polymers.

[12] Silva, H. (2015). Nanopartículas de Prata Conjugadas com Hiclato de Doxiciclina: Síntese, caracterização e avaliação da atividade antimicrobiana contra Escherichia coli. . p. 77p.

[13] Dedavid, C. I. (2007). Microscopia Eletrônica de Varredura. In: Aplicações e preparações de amostras - Materiais poliméricos, metais e semicondutores. ediPUCRS.

[14] Guedes, A. E. (2017). Síntese e Caracterização de Nanopartículas Superparamagnéticas para Aditivação de Lubrificantes Industriais.

[15] Schnablegger., \& Singh, Y. (2013). The Saxs Guide: Getting acquainted with the principles.

[16] Schnablegger, H. (2006). Gettin acquainted with the principles - A practical guide to SAXS.

[17] Hu, W., Gao, S., Prasad, P., Wang, J., \& Xu, J. (2012). Employing photoassisted ligand exchange technique in layered quantum dot LEDs. Journal of Nanomaterials.

[18] Guedes, A. E. (2017). Síntese e Caracterização de Nanopartículas Superparamagnéticas para Aditivação de Lubrificantes Industriais.

[19] Oliveira, C. (2011). Current trends in x-ray crystallography.

[20] Langevin, D., Poteau, S., Hénaut, I., \& Argillier, J. (2004). Crude oil emulsion properties and their application to heavy oil transportation. Oil \& Gas Science and Technology - Rev. IFP.

[21] Guedes, A. E. (2017). Síntese e Caracterização de Nanopartículas Superparamagnéticas para Aditivação de Lubrificantes Industriais. 